\title{
PEMBERDAYAAN ANAK JALANAN DI RUMAH SINGGAH
}

\author{
Oleh: \\ Fikriryandi Putra, Desy Hasanah St. A, \& Eva Nuriyah H \\ Email: \\ fikriryandi@gmail.com; desyhasanah@yahoo.com; enuriyah@yahoo.co.id
}

\begin{abstract}
ABSTRAK
Tulisan ini akan menggambarkan pemberdayaan anak jalanan yang dilakukan oleh Rumah Singgah. Untuk memperoleh data tersebut tulisan ini menggunakan studi literatur yang berupa kajian konseptual. Hasil tulisan ini melihatkan bahwa program penanganan anak jalanan telah dilakukan yang salah satunya adalah dengan menggunakan, pendekatan Rumah Singgah. Rumah Singgah menggunakan pendekatan centre based program dengan fungsi intervensi rehabilitatif. Meskipun demikian Rumah Singgah juga menggunakan pendekatan community based dan street based yang tercermin dalam beberapa program dan kegiatannya yaitu dengan melakukan pemberdayaan. Pemberdayaan mencakup sasaran yang diharapkan untuk mengatasi permasalahan sosial anak jalanan dengan meningkatkan kemampuan dirinya melalui pendidikan, pelatihan keterampilan dan pendidikan moral. Hal ini diupayakan untuk bisa mendorong dan menstimulasi supaya anak jalanan tersebut bisa mendapatkan hak untuk mendapatkan hidup yang lebih layak, perlindungan, dan bisa menampilkan perilaku positif sesuai dengan norma dan etika yang ada di lingkungan masyarakat. Adapun tahapan pelayanan atau kegiatan tersebut adalah penjangkauan, identifikasi, resosialisasi, pemberdayaan dan terminasi. Program pemberdayaan ditujukan untuk meningkatkan kemampuan anak jalanan sehingga mempunyai pengetahuan yang meningkat, dapat mandiri sehingga anak jalanan tidak beraktivitas di jalan lagi.
\end{abstract}

\begin{abstract}
This article will describe the empowerment of street children conducted by Open House for Street Children. To obtain the data of this paper uses literature in the form of a conceptual study. Results of this paper that show some programs handling street children have done that one is using, Open House for Street Children. Open House for Street Children have some of the programs and activities by doing empowerment. Empowerment includes the expected goals to overcome the social problems of street children to improve themselves by education, skills training and moral education. It is attempted to be able to encourage and stimulate so that the street children can get the right to get a better life, protection, and can display positive behavior in accordance with the norms and ethics that exist in society. As for step services or activities are outreach, identification, resocialization, empowerment and termination. Empowerment program intended to improve the ability of street children so as to have an increased knowledge, can independently so that street children are not active on the road again.

Keywords. Pemberdayaan, Anak Jalanan, Rumah Singgah
\end{abstract}

\section{PENDAHULUAN}

\section{Latar belakang}

Anak sebagai generasi penerus dan aset bangsa, perlu mendapatkan perhatian yang serius, karena maju mundurnya suatu negara akan sangat tergantung pada generasi saat ini dan masa yang akan datang. Karena itu kesejahteraan anak harus dikedepankan agar terlahir generasi-generasi penerus yang berkualitas. Kesejahteraan anak sebagai bagian dari upaya menciptakan sumber daya manusia yang berkualitas hanya akan terwujud apabila semua pihak dapat menghormati dan memperlakukan anak sesuai hak-haknya. Apabila anak tidak mendapatkan hak-haknya dan perlindungan sosial sebagai salah satu pilar bangsa, mereka akan cenderung mengalami masalah atau menjadi masalah. Salah satu masalah 
anak yang masih menjadi perhatian di Indonesia saat ini adalah masalah anak jalanan. Masalah anak jalanan ini dipandang sebagai masalah yang memberi pandangan negatif terhadap pembangunan. Keberadaan mereka tidak jarang dijadikan indikator kemelaratan dan krisis nilai-nilai sosial Aep (2001:5).

Pada dasarnya anak jalanan adalah kelompok anak yang menghadapi banyak masalah Mulandar (1996:153). Menurut UNICEF Anak jalanan merupakan anak-anak yang berumur di bawah 16 tahun yang sudah melepaskan diri dari keluarga, sekolah, dan lingkungan masyarakat terdekat, larut dalam kehidupan yang berpindah-pindah di jalan raya. Akan tetapi tidak semua anak jalanan tidak memiliki hubungan dengan orang tua. Menurut UNICEF (1986) yang dikutip oleh Lusk dalam Journal of Sociology \& Social Welfare (1989:59) anak jalanan di bagi 3 kategori: Anak yang mempunyai resiko tinggi (children at high risk), Anak yang bekerja di jalan (children on the street) dan anak yang hidup di jalan (children of the street).

Laporan Yayasan Kesejahteraan Anak Indonesia (2004) memberikan bahwa fenomena anak jalanan semakin meningkat baik segi kualitas maupun kuantintitas. Permasalahan yang dialami anak jalan berbagai macam seperti tindak kekerasan baik fisik, psikis ekonomi, maupun kekerasan sosial. Kebanyakan kekerasan akibat dari ketidak maupuan orang tua yang tidak dapat memenuhi kebutuhan dasar mereka, diantaranya faktor-faktor intermediasi seperti harmoni keluarga, kemampuan pengasuhan anak dan langkanya dukungan keluarga pada saat krisis keluarga dirumah.

Berdasarkan data Hasil Survei Sosial Ekonomi Nasional (SUSENAS) Badan Pusat Statistik Republik Indonesia tahun 2008, menunjukkan bahwa anak jalanan secara nasional berjumlah sekitar 2,8 juta anak. Dua tahun kemudian, tahun 2010, angka tersebut mengalami kenaikan sekitar $5,4 \%$, sehingga jumlahnya menjadi 3,1 juta anak. Pada tahun yang sama, anak yang tergolong rawan menjadi anak jalanan berjumlah 10,3 juta anak atau $17,6 \%$ dari populasi anak di Indonesia, yaitu 58,7 juta anak (Soewignyo, 2010).

Hidup dan berada di jalanan bukanlah tempat yang layak untuk membantu tumbuh kembang anak secara optimal karena resiko eksploitasi dan ancaman kekerasan merupakan dua hal yang terkadang sekaligus dialami dan terpaksa dirasakan oleh anak jalanan. Sehingga resiko tinggal atau hidup dijalan akan melekat pada diri anak dan anak menjadi tidak mempunyai keterampilan di sektor lain, tidak memiliki identitas diri dengan sempurna, internalisasi perilaku, traumatized dan stigamatized serta reproduksi kekerasan (Handayani, 1999).

Anak jalanan memiliki banyak pengalaman yang berasal dari budaya keras dan tidak semuanya diterima oleh masyarakat. Oleh karena itu, perlu ada pendekatan dan penanganan dalam membantu mengembangkan proses berfikir mereka, mengajarkan begaimana membangun hubungan antara masa lalu, masa sekarang dan masa depan, dengan mengarahkan mereka kepada pola-pola perilaku yang dapat diterima masyarakat. Salah satu kebutuhan dasar yang harus dipenuhi agar anak mengalami proses tumbuh kembang optimal adalah kebutuhan stimulasi atau pendidikan yang mempengaruhi proses berfikir, berbahasa, sosialisasi dan kemandirian seoarang anak Hurlock (1978:257) dan menurut Suharto (1997:363) sejak dini mereka perlu pendidikan dan sosialisasi dasar, pengajaran tanggung jawab sosial, peran-peran sosial dan keterampilan dasar agar menjadi warga masyarakat yang bermanfaat.

Penanganan masalah anak jalanan sangat penting untuk dilakukan dan diperhatikan, disamping hak anak untuk mendapatkan pelayanan kesejahteraan yang telah dilindungi oleh undang-undang, juga untuk menghindari dampak negatif apabila masalah anak marjinal ini tidak dapat terpecahkan. Kita harus menyadari bahwa terhambatnya pemenuhan hak-hak anak terutama pada anak jalanan akan berdampak pada kelangsungan hidup anak itu sendiri, bangsa dan negara Indonesia.

Saat ini pemerintah maupun masyarakat banyak memberikan perhatian yang cukup tinggi, yaitu dengan dilihat dengan munculnya organisasi sosial yang telah banyak memberikan program-program yang membantu memenuhi kebutuhan anak jalanan dan mewujudkan kesejahteraan anak jalanan. Oleh karena itu, model pertolongan 
terhadap anak jalan bukan sekedar menghapus anak-anak dari jalanan, melainkan harus bisa meningkatkan kualitas hidup sekurang-kurangnya melindungi mereka dari situasi yang eksploitatif dan membahayakan. Mengacu pada prinsipprinsip profesi pekerjaan sosial yakni salah satunya adalah konsep pemberdayaan yang dimana dikemukakan oleh Hogan (2000:13) yang mengutip dari pandangan Rotter (1966), Selignan (1975), dan Hopson dan Scally (1995) dalam Adi (2008:212) yang melihat proses pemberdayaan individu sebagai suatu proses yang relatif terus berjalan sepanjang usia manusia yang diperoleh dari pengalaman individu tersebut dan bukannya suatu proses yang berhenti pada suatu masa saja.

Proses pemberdayaan mengandung dua kecenderungan, pertama yang menekankan pada proses pemberian atau pengalihan sebagian kekuasaan, kekuatan atau kemampuan kepada masyarakat agar individu lebih berdaya. Kedua, kecenderungan yang menekankan pada proses menyelimuti, mendorong atau memotivasi agar individu mempunyai kemampuan atau keberdayaan untuk menentukan apa yang menjadi pilihan hidupnya. Hal ini sejalan dengan tujuan pemberdayaan bagi anak jalanan yakni tidak hanya sekedar memenuhi kebutuhan atau hak anak jalanan yang terampas karena berkeliaran dijalan, tetapi juga ingin menanamkan penguasaan hak dan memberi peluang agar potensi setiap anak dapat teridentifikasi kemudian dikembangkan. Tujuan tersebut antara lain untuk mengembalikan rasa percaya diri dan rasa aman, membuka wacana pada masalah yang dihadapi anak, kemapuan bertahan hidup, serta pembekalan diri untuk masa depan Indrasari Tjandraningsih (1996:3)

Maka pemberdayaan anak jalanan ini adalah suatu proses pemberian kemampuan yang berupaya agar anak jalanan dapat memotivasi, mendorong dirinya guna memperoleh daya dan memaksimalkan daya yang ia miliki untuk menentukan tindakan, termasuk mengurangi efek negatif atau hambatan yang ada di dalam dirinya dan lingkugannya. Dengan kegiatan peningkatan kualitas anak jalanan melalui pemberian pendidikan, pelatihan dan belajar usaha agar mereka menjadi warga masyarakat yang produktif. Hal ini dapat diumpamakan dengan memberi kail kepada anak jalanan dengan harapan ketika, ikan yang dikonsumsi anak jalanan habis, anak jalan ini akan kembali berusaha mengailnya sendiri karena mereka punya cara sendiri untuk hal itu. Dengan demikian, pemberdayaan anak jalanan ini menjadi sangat startegis karena dapat menyelamatkan anak jalanan dengan mencegah berbagai masalah lain, baik dalam menghindari eksploitasi dalam pekerjaan maupun masalah dalam penampilan perilaku.

Di Indonesia, kepedulian terhadap kesejahteraan anak sebagai bagian dari upaya peningkatan kualitas sumber daya manusia telah lama menjadi komitmen. Hal itu diantaranya ditunjukan dalam UUD 1945 pasal 34, yang menyebutkan bahwa "Fakir miskin dan anak terlantar dipelihara oleh negara". Pemerintah juga telah mengeluarkan UU No.4 tahun 1979 tentang Kesejahteraan Anak dan UU No.23 Tahun 2002 tentang perlindungan anak. Melihat Undang-undang tersebut yang terdapat adanya jaminan atas hak anak, penanganan masalah anak jalanan sangat penting untuk dilakukan dan diperhatikan, disamping hak anak untuk mendapatkan pelayanan kesejahteraan yang telah dilindungi oleh undang-undang, juga untuk menghindari dampak negatif apabila masalah anak marjinal ini tidak dapat terpecahkan.

Departemen Sosial RI bekerja sama dengan UNDP (United Nation United Programe) dalam proyek INS/94/007 pembuatan Rumah Singgah (Departemen Sosial,1997:31) model Rumah Singgah (Open House For Street Children), secara konseptual menggunakan metode dan teknik yang meliputi street based, centre based, community based, bimbingan sosial dan pemberdayaan (Depsos RI, 1999 : 2) Model tersebut yang dapat dikatakan Rumah Singgah merupakan salah satu alternatif startegi penanganan anak jalanan yang dimana didalamnya telah masuk pemberdayaan anak jalanan pada aspek pendidikan, kesehatan, ekonomi, kesenian dan agama. Secara umum tujuan dibentuknya Rumah Singgah adalah membantu anak jalan dalam mengatasi masalah-masalah dan menemukan altrenatif 
untuk pemenuhan hidupnya (Armai Arif, 2002:1).

Rumah Singgah merupakan suatu wahana yang dipersiapkan sebagai perantara antara anak jalanan dengan pihak yang akan membantu mereka kegiatan, pelaksanaan penanganan masalah anak jalanan melalui Rumah Singgah. Berdasarkan pedoman Penyelenggaraan Pembinaan Anak Jalanan Melalui Rumah Singgah (Depsos, 1999:31-34) pelayanan dan kegiatan Rumah Singgah terbagi ke dalam 6 tahapan. Tahapantahapan tersebut mencangkup: Penjangkauan, Identifikasi anak, resosialisasi, pemberdayaan anak, pemberdayaan orang tua dan terminasi. Dengan demikian tulisan ini ingin menggambarkan pemberdayaan anak jalanan melalui Rumah Singgah..

\section{Hasil dan Pembahasan}

\section{Anak jalanan}

Anak jalanan adalah sebuah realitas yang menjadi bagian dari pemandangan kehidupan perkotaan yang secara awam, masyarakat sering mendefinisikan anak jalanan berdasarkan jenis pekerjaan yang dilakukannya. Mereka sering disebut sebagai pengamen, pemulung, pendagang asongan, pengemis, penjual koran, pengojek payung, penyemir sepatu, tukang parkir, pembersih mobil, joki dan lain sebagainya. Pemberian definisi terhadap anak jalanan yang berbedabeda ini ternyata terjadi tidak hanya di kalangan individu tetapi juga di kalangan aktivis lembaga swadaya masyarakat maupun oleh negara. Pendefinisian anak jalanan dengan mudah dapat berbeda-beda.

United Nation Children's Fund (UNICEF) dalam Bakhrul (2003:18) mengemukakan definisi dari anak jalanan adalah sebagai berikut:

"Anak jalanan merupakan anak-anak yang berumur di bawah 16 tahun yang sudah melepaskan diri dari keluarga, sekolah, dan lingkungan masyarakat terdekat, larut dalam kehidupan yang berpindah-pindah di jalan raya."

Dari definisi ini menujukan pada anakanak yang telah meninggalkan rumah dan juga telah meninggalkan sekolah sebelum usia 16 tahun dan hidup tidak menetap di jalanan. Anak jalan ini bisa masih mempunyai ikatan dengan keluarganya atau sudah mempunyai sudah tidak mempunyai ikatan dengan keluarganya.

Menurut UNICEF (1986) yang dikutip oleh Lusk dalam Journal of Sociology \& Social Welfare (1989:59) menyebutkan bahwa:

"kelompok remaja terbagi dalam tiga kategori: anak dalam resiko tinggi, anak yang berkerja dijalan dan anak yang hidup di jalan"

Anak yang mempunyai resiko tinggi (children at high risk) adalah anak yang mempunyai resiko tinggi untuk menjadi anak jalanan. Mereka belum menjadi anak jalanan, murni, tetapi masih tinggal dengan orang tuanya. Kerentanan ini bisa dilihat juga dari kondisi ekonomi orang tuanya yang rentan, sehingga suatau saat anak tersebut bisa menjadi anak jalanan. Anak-anak seperti ini hidup di lingkungan kemiskinan absolut atau di daerah slum.

Anak yang berkerja di jalan (children on the street) yaitu mereka yang menghabiskan sebagian besar waktunya di jalanan atau ditempat-tempat umum lainnya untuk bekerja dan penghasilannya digunakan untuk membantu keluarganya. Anak-anak tersebut mempunyai kegiatan ekonomi (sebagai pekerja anak) di jalan adan masih mempunyai hubungan yang kuat dengan orang tua mereka. sebagain penghasilan mereka di jalan diberikan kepada orang tuanya.

Anak-anak yang hidup di jalan (children of the street) adalah mereka yang menghabiskan sebagian besar waktunya di jalanan atau di tempat-tempat umum lainnya, tetapi hanya sedikit waktu yang digunakan untuk bekerja. Mereka jarang berhubungan dengan keluarganya. Beberapa diantara mereka tidak memiliki rumah tinggal (homeless), mereka hidup di sembarang tempat. Banyak diantara mereka adalah anak-anak yang karena suatu sebab lari atau pergi dari rumah. Anak-anak ini sangat rawan terhadapp perlakuan salah baik secara emosional, fisik, maupun seksual. Biasanya perlakuan salah ini datan dari mereka yang lebih dewasa.

Hakekatnya pengertian tentang anak jalanan ini menunjukan bahwa kenyataannya anak jalanan diperlakukan tidak seperti konsep-konsep yang dikemukakan di atas.banyak permasalahan anak jalanan yang 
terjadi pada kehidupan sesugguhnya yang menyebabkan anak jalanan merupakan generasi yang hilang, yaitu suatu generasi yang keberadaannya tidak mendapatkan perhatian, sehingga jaminan akan hidup yang layak tidak didapatkan sebagaimana seorang anak. Seperti apa yang dikatakan Suyoto (2010:185) mendefinisikan anak jalanan yang lebih menitikberatkan kepada hal-hal yang dihadapi oleh anak jalanan, dengan mendefiniskan:

"Anak jalanan adalah anak-anak yang tersisihkan, marjinal dan teralienasi dari perlakuan kasih sayang karena kebanyakan dalam usia yang relatif dini sudah harus berhadapan dengan lingkungan kota yang keras dan kadang tidak bersahabat."

Dari definisi tersebut dapat disimpulkan bahwa anak jalanan adalah anak yang berusia 7-16 tahun yang menggunakan sebagian waktunya dijalan untuk bermain maupun bekerja. Mereka adalah anak-anak yang yang tinggal bersama orang tua dan keluarga yang hidup di jalanan, tinggal terpisah dengan orang tuanya, diterlantarkan, memutuskan hubungan dengan lari dari keluarga mereka. Sebagian anak jalanan juga terkadang mendapatkan perlakuan yang tidak sesuai dimasyarakat, dengan diperlakukan sebagai kelompok tersisihkan dan marjinal di perkotaan dan dieksploitasi oleh oknum-oknum di masyarakat. Hal ini menyebabkan anak jalanan rentan karena harus menanggung resiko-resiko berhadapan dengan lingkungan kota.

\section{Faktor-faktor Yang mempengaruhi munculnya anak jalanan}

Anak jalanan yang ada di perkotaan tidak hanya muncul begitu saja tanpa adanya faktor-faktor yang mempengaruhinya. Sudrajat (1996:154) mengemukakan penyebab munculnya anak jalanan meliputi tingkat mikro, mezzo dan makro, yang dapat diuraikan sebagai berikut:

1) Tingkat mikro (immediate causes)

Yakni faktor yang berhubungan dengan anak dan keluarganya seperti lari dari keluarga, dipaksa bekerja, berpetualang, diajak temen, kemiskinan keluarga, ditolak atau kekerasan atau terpisah dari orang tua.

2) Tingkat Mezzo (underlying causes)

Yakni faktor di masyarakat seperti kebiasan mengajarkan untuk bekerja sehingga suatu saat menjadi keharusan dan kemudian meninggalkan sekolah, kebiasaan pergi ke kota untuk mencari pekerjaan karena keterbatasan kemampuan di daerahnya.

3) Tingkat makro (basic causes)

Yakni faktor yang berhubungan dengan struktur makro, seperti peluang pekerjaan pada sektor informal yang tidak terlalu membutuhkan modal dan keahlian yang besar, urbanisasi, biaya pendidikan yang tinggi dan perilaku guru yang diskriminatif, belum adanya kesamaan persepsi instansi pemerintah terhadap anak jalanan.

\section{Strategi Pemberdayaan Anak Jalanan}

Pemberdayaan

merupakan

terjemahan dari bahasa inggris yaitu "empowerment" yang secara harafiah berarti "pemberkuasaan". Pemberkuasaan itu sendiri dapat dipahami sebagai upaya memberikan atau meningkatkan kekuasaan (power) kepada pihak yang lemah atau kurang beruntung (disadvantaged). Pemberdayaan merupakan upaya untuk membangun eksistensi seseorang dalam kehidupan dengan memberi dorongan agar memiliki kemampuan.

Model penampungan anak jalanan dimulai pada tahun 1981. Pada tahun itu, Longres, mengadakan suatu pengamatan tentang strategi intervensi dan programprogram yang bertujuan untuk menangani masalah sosial ini. Longres. Menghubungkan antara asumsi dan ideologi yang membentuk masalah tersebut, serta menjadi normanorma dasar dilakukannya intervensi. Ia mengembangkan faktor-faktor yang bisa digunakan untuk mengidentifikasi normanorma dasar dari suatu intervensi sosial berdasarkan pengamatan tersebut, Lusk (1984) melihat faktor-faktor yang dibuat Longres dapat digunakan untuk memahami intervensi sosial pada anak jalanan. Startategi yang dibuat Longres berawal dari adabtasi sistem sosial ekonomi hingga kebutuhan 
individu, dari adabtasi individu hingga prasarat sistem sosial. dengan demikian pengembangan program strategi intervensi bagi anak jalanan tersebut meliputi:

1) Pendekatan Koreksional (Correctional/Instutionalization)

Fenomena anak jalanan dalam pandangan ini didominasi oleh pemikiran sebagian besar polisi dan pengadilan anak yang memang banyak berurusan dengan anak jalanan. Pemikiran inilah yang mempengaruhi pandangan masyarakt untuk melihat anak jalanan sebagai perilaku nakal. Sebab itu intervensi yang cocok adalah dengan memindahkan anak dari jalanan dan memperbaiki perilaku mereka. pendekatan ini menempatkan pentingnya "mendidik kembali" (adapt the deviant behaviour) agar sesuai dengan norma yang berlaku di masyarakat. Kelemahan pendekatan ini adalah adanya kenyataan bahwa para petugas dipandang oleh anak sebagai musuh ketimbang mitra (partner) juga adanya kenyataan bahwa kekerasan dan pelecehan seksual tetap berkembang

2) Pendekatan Rehabilitas

Para profesional memperdebatkan bahwa anak jalanan bukanlah perilaku menyimpang karena banyak dari mereka justru merupakan korban penganiayaan dan penelantaran, dampak kemiskinan dan kondisi rumah yang tidak tetap. Anak jalanan dilihat sebagai anak yang dirugikan oleh lingkungannya, sehingga mengakibatkan banyak gereja dan program-program sukarela yang muncul. Pendekatan rehabilitatif memandang anak jalanan sebagai anak yang berada dalam kondisi ketidakmampuan (inadequate), membutuhkan (needy), ditelantarkan (abandoned), dirugikan (harmed), sehingga intervensi yang dilakukan adalah dengan melindungi dan merehabilitasi. Pada saat ini kegiatan dari pendekatan rehabilitatif ini lebih dikenal dengan center based program

3) Pendidikan yang dilakukan di jalanan (Street Education)
Pendekatan ini mengasumsikan bahwa hal terbaik untuk menanggulangi masalah anak jalanan adalah dengan mendidik dan memberdayakan anak jalanan. Para pendidik jalanan yakin kesenjangan struktur sosial merupakan peneyebab dari masalah ini. Menurut mereka anak merupakan individu normal yang didorong oleh kesenjangan kondisi masyarakat yang hidup di bawah keadaan yang sulit. Dengan melibatkan partisipasi dari anak jalanan itu sendiri, maka dapat dipelajari tentang situasi mereka dan mengikutsertakan dalam aksi bersama guna menemukan pemecahan dari masalah bersama. Bentuk kegiatan dari pandangan pendidikan jalanan pada saat ini lebih dikenal dengan nama program yang berpusat di jalanan atau street based program.

Street based adalah program yang berusaha untuk memberikan hak-hak anak jalanan, khususnya mereka yang memiliki hubungan tidak teratur dengan keluarga. strategi ini menghendaki, mengenal terlebih dahulu kebutuhan anak untuk mempertahankan hidup dan pendapatnya. Jadi bukan untuk mendorong anak agar kembali pada keluarga atau mengirim mereka ke lembaga (pusat pelayanan) melalui program ini, dampak negatif dari kehidupan jalanan bagi anak dikurangi dengan kegiatan yang memungkinkan bakat dan minat anak untuk tampil.

4) Pencegahan (preventif)

Pendekatan ini memandang penyebab dari masalah anak jalanan adalah dorongan dari masyarakat itu sendiri. Strategi pencegahan berusaha memberikan pendidikan dan pembelaan (advocacy) serta mencoba menemukan penyelesaian dari apa yang diperkirakan menjadi penyebab permasalahannya. Yaitu dengan cara berusaha menghentikan kemunculan anak di jalanan. Mengatasi masalah anak jalanan, bukan hanya anak jalanan yang dijadikan fokus untuk dapat menyesuaikan diri dalam masyarakat, mengingat masyarakat 
sendiri terus mengalami perubahan sesuai dengan pembangunan yang berlangsung. Bentuk kegiatan dari pandangan preventif ini dikenal dengan community based program. Program ini membantu anak yang masih memiliki hubungan dengan keluarga agar dapat melakukan hubungan tersebut. Program ini didasarkan pada suatu keyakinan bahwa suatu cara yang terbaik mencegah terjadinya kehancuran nilai keluarga yang akhirnya menyebabkan terlemparnya anak menjadi anak jalanan adalah dengan menguatkan dasar keluarga tersebut serta mengorganisir keluarga sebagai komunitas yang mandiri.

Dipandang dari fungsi intervensi, penganan anak jalanan diatas, terjadi tumpang tindih dengan jenis pendekatan yang dilakukan. Secara ringkas model dan pendekatan yang dikembangkan di banyak negara dan digunakan oleh LSM (lembaga Swadaya Masyarakat) menurut Lusk (1989 67-74) yang dikutip Sudrajat (1997:4), untuk menangani anak jalanan meliputi:

\section{1) Street Based}

Merupakan penganan di jalan atau tempat-tempat anak jalanan berada, kemudian para street educator datang kepada mereka, berdialog, mendampingi mereka bekerja, memahami dan menerima situasinya serta menempatkan diri sebagai teman. Dalam beberapa jam, anakanak diberikan materi pendidikan dan keterampilan, di samping itu anak jalanan memperoleh kehangatan hubungan dan perhatian yang bisa menumbuhkan kepercayaan satu sama lain yang berguna bagi pencapaian tujuan intervensi.

\section{2) Centre Based}

Pendekatan ini merupakan penanganan di lembaga atau panti. Anak-anak yang masuk dalam program ini di tampung dan diberikan pelayanan di lembaga atau panti seperti pada malam hari diberikan makanan dan perlindungan, serta perlakukan yang hangat dan bersahabat dari pekerja sosial. pada panti yang permanen disedikan pelayanan pendidikan, keterampilan, kebutuhan dasar, kesehatan, kesenian, dan pekerjaan. Dalam penanganan di lembaga atau di panti terdapat beberapa jenis atau model penampungan yang bersifat sementara (drop in centre) dan tetap (residential centre) untuk anak jalanan yang masih bolak balik ke jalan biasanya dimasukan ke dalam drop in centre, sedangkan untuk anak-anak yang sudah benar-benar meninggalkan jalanan akan di tempatkan di residential centre.

3) Community Based

Di dalam community based penanganan melibatkan seluruh potensi masyarakat, utamanya keluarga atau orang tua anak jalanan. Pendekatan ini bersifat preventif, yakni mencegah anak-anak turun ke jalan. Keluarga diberikan kegiatan penyuluhan pengasuhan anak dan peningkatan taraf hidup, sementara anak-anak diberi kesempatan memperoleh pendidikan formal maupun informal, pengisian waktu luang dan kegiatan lainnya. Pendekatan ini bertujuan meningkatkan kemampuan keluarga dan masyarakat agar sanggup melindungi, mengasuh dan memenuhi kebutuhan anak-anaknya.

Tabel 1

Pendekatan dan Penanganan Anak Jalanan

\begin{tabular}{|l|c|c|}
\hline $\begin{array}{c}\text { Pengelompokan Anak } \\
\text { Jalanan }\end{array}$ & $\begin{array}{c}\text { Pendidikan } \\
\text { Program/St } \\
\text { rategi }\end{array}$ & $\begin{array}{c}\text { Fungsi } \\
\text { Intervensi }\end{array}$ \\
\hline $\begin{array}{l}\text { Anak yang masih } \\
\text { berhubungan/tinggal } \\
\text { dengan orang tua }\end{array}$ & $\begin{array}{c}\text { Community } \\
\text { based }\end{array}$ & Preventif \\
\hline $\begin{array}{l}\text { Anak yang masih ada } \\
\text { hubungan dengan } \\
\text { keluarga tetapi jarang } \\
\text { berhubungan/tinggal } \\
\text { dengan orang tua }\end{array}$ & Street & $\begin{array}{c}\text { Perlindunga } \\
\text { Based }\end{array}$ \\
\hline $\begin{array}{l}\text { Anak tersisih/putus } \\
\text { hubungan dengan } \\
\text { keluarga/orang tua }\end{array}$ & Centre & Rehabilitasi \\
\hline
\end{tabular}

Sumber: Mulandar (2010:159) 
Bila pendeketan program/strategi di atas dihubungkan dengan tipologi anak jalan, maka akan tampak pada tabel 2.1. Dari tabel 2.1 ini juga diketahui fungsi intervensi lebih dari satu, namun yang ditulis merupakan fungsi utama.

\section{Pendampingan dalam Pemberdayaan Anak Jalanan}

Sudah semakin banyaknya programprogram pemberdayaan pada bidang kesejahteraan sosial beberapa tahun belakangan ini, sudah juga melazimkan penggunan "pendampingan" untuk menyebut upaya-upaya pekerja sosial dalam melaksanakan tugasnya meningkatkan taraf kesejahteraan bagi individu, kelompok atau masyarakat yang mengalami ketidakberdayaan dan ketidakberfungsian sosial.

Menurut Midgley (1997:117) untuk melaksanakan tugas tersebut harus dilakukan oleh para profesional tenaga terlatih yang berasal dari luar komunitasnya. Meskipun demikian dimungkinkan juga menggunakan tenaga dari petugas-petugas lokal dalam rangka memobilisasi partisipasi lokal, mengorganisir kegiatan serta menghubungkan dengan sistem sumber ataupun kelembagaan setempat.

Perlunya pendampingan dalam usaha menyelesaikan masalah anak jalanan didasarkan pada sebuah asumsi bahwa anak jalanan merupakan penyandang masalah yang kompleks. Sehingga pemberdayaan yang dilakukan tak ubahnya sebagai upaya membantu mereka dalam mengatasi masalah-masalahnya serta menemukan alternatif untuk pemenuhan kebutuhan hidupnya (Departemen Sosial RI, 1999:5.) oleh karena itu, Ife (1997:201) menyarankan bahwa kegiatan pendampingan harus dilaksanakan secara generalis. Untuk itu pula seorang pendamping harus mampu memerankan tugas dan fungsinya sebagai berikut:

\section{1) Fasilitative Roles}

Sebagai fasilitator seorang pendamping harus mampu merangsang dan mendukung kemajuan individu atau komutas yang didampingi.

\section{2) Education Roles}

Dalam menjalankan peran ini seorang pendamping harus secara aktif memberikan berbagai masukan yang positif serta direktif sebagai bagian dari pengalaman-pengalamannya.

3) Representational Roles

Dalam kerangka pelaksanaan ini seorang pendamping berinteraksi dengan lembaga-lembaga eksternal atas nama individu ataupun masyarakat untuk kepentingan dampingannya.

4) Technical Roles

Peran teknis lebih mengacu pada aplikasi keterampilan yang bersifat teknis. Dalam peran ini pendamping dituntut tidak hanya mampu mengorganisir kelompok, tetapi juga tugas-tugas teknis seperi pengumpulan dan analisis data, penggunaan peralatan penunjang, pengelolaan administrasi maupun pengendalian keuangan.

\section{Rumah Singgah}

Perhatian khusus pemerintah terhadap anak jalanan baru muncul sekitar tahun 1998, yaitu dengan mendirikan Rumah Singgah bagi anak jalalanan. Pembentukan Rumah Singgah merupakan upaya pelayanan kesejahteraan sosial terhadap anak jalanan yang di landasi oleh UUD 1945 pasal 34. Rumah Singgah sendiri menurut Departemen Sosial didefinisikan sebagai suatu wahanan yang akan dipersiapkan sebagai perantara antara anak jalanan dengan pihak-pihak yang akan membantu mereka mereka. Rumah Singgah merupakan proses informal yang memberikan suasana resoalisasi anak jalanan terhadap sistem nilai dan norma yang berlaku di masyarakat. Rumah Singgah merupakan tahap awal bagi seorang anak untuk memperoleh pelayanan selanjutnya, oleh karenanya penting menciptakan Rumah Singgah sebagai tempatt yang aman, nyaman, menarik dan menyenangkan bagi anak jalanan.

Tujuan Rumah Singgah adalah membantu anak jalan mengatasi masalahmasalahnya dan menemukan alternatif untuk pemenuhan kebutuhan hidupnya. Sedangkan tujuan khususnya adalah:

1) Membentuk kembali sikap dan perilaku anak yang sesuai dengan nilai dan norma yang berlaku di masyarakat.

2) Mengupayakan anak-anak kembali ke rumah jika memungkinkan atau ke panti 
dan lembaga pengganti lainnya jika diperlukan.

3) Memberikan berbagai alternatif pelayanan untuk pemenuhan kebutuhan anak dan menyiapkan masa depannya sehingga menjadi warga masyarakat yang produktif.

Menyiapkan masa depannya sehingga menjadi warga masyarakat yang produktif. Rumah Singgah memiliki fungsi sebagai berikut:

1) Fasilitatornya (perantara dengan keluarga/lembaga lain)

Rumah Singgah merupakan perantara anak jalanan dengan keluarga, panti, keluarga pengganti, dan lembaga lainnya. Anak jalanan diharapkan tidak terus menerus bergantung kepada Rumah Singgah melainkan dapat memperoleh kehidupan yang lebih baik melalui atau setelah proses yang dijalaninnya.

2) Kuratif-Rehabilitatif (mengembalikan dan menanamkan fungsi sosial bagi anak).

Dalam fungsi ini, para pekerja sosial diharapkan mampu mengatasi permasalahan anak jalanan dan membetulkan sikap dan perilaku seharihari yang akhirnya akan mampu menumbuhkan keberfungsian sosialan anak. cara-cara atau intervensi profesional dilakukan untuk fungsi ini termasuk menggunakan konselor yang sesuai dengan masalahnya.

3) Perlindungan

Rumah Singgah dipandang sebagai tempat anak berlindung dari kekerasan/penyalahgunaan seks, ekonomi, dan bentuk-bentuk yang terjadi dijalanan.

4) Pusat informasi

Rumah Singgah menyediakan informasi berbagai hal yang berkaitan dengan kepentingan anak jalanan seperti data dan informasi tentang anak jalanan, bursa kerja, pendidikan, kursus keterampilan dan lain-lain.

5) Akses terhadap pelayanan

Sebagai persinggahan, Rumah Singgah menyediakan akses kepada berbagai pelayanan sosial. Pekerja Sosial membantu anak mencapai pelayanan tersebut.

6) Lokasi Rumah Singgah berada di tengahtengah lingkungan masyarakat sebagai upaya mengenalkan kembali norma, situasi, dan kehidupan bermasyarakat bagi anak jalanan. Pada sisi lain mengarah pada pengakuan, tanggung jawab, dan upaya masyarakat terhadap penanganan masalah anak jalanan ini.

7) Pusat rujukan

Dalam fungsi ini Rumah Singgah menjadi rujukan bagi anak jalanan terhadap kebutuahn dan masalah yang tidak terpenuhi di jalanan.

\section{Prinsip-prinsip Rumah Singgah}

1) Semi Institusional

Dalam bentuk ini anak jalanan sebagai penerima pelayanan boleh bebas keluar masuk, baik untuk tinggal sementara maupun hanya mengikuti kegiatan.

2) Pusat kegiatan

Rumah Singgah merupakan tempat kegiatan, pusat informasi, dan akses bagi seluruh kegiatan baik yang dilakukan di dalam maupun di luar Rumah Singgah.

3) Terbuka 24 jam

Rumah Singgah terbuka 24 jam bagi anak. mereka boleh datang kapan saja, siang hari maupun malam hari terutama bagi anak jalanan yang baru mengenal Rumah Singgah. Para pekerja sosial siap dikondikan untuk menerima anak dalam 24 jam tersebut.

4) Hubungan Informal (kekeluargaan) Hubungan-hubungan yang terjadi di Rumah Singgah bersifat informal seperti perkawanan atau kekeluargaan. Anak jalanan dibimbing untuk merasa sebagai anggota keluarga besar dimana para pekerja sosial berperan sebagai teman, saudara/kakak atau orang tua.

5) Bebas untuk apa saja bagi anak Di dalam Rumah Singgah anak jalan dibebaskan untuk melakukan apa saja, seperti tidur, bermain, bercanda, bercengkrama, mandi dan sebagainya. Meskipun demikian, perilaku yang negatif seperti perjudian, merokok, minuman keras dan sejenisnya dilarang. Peraturan dibuat dan disepakati oleh anak-anak.

6) Persinggahan dari jalanan ke rumah atau ke alternatif lain

Pengertian singgah sebagai berikut:

a. Anak jalanan boleh tinggal sementara untuk tujuan perlindungan. Biasanya dihadapi oleh anak yang hidup di 
jalanan yang tidak mempunyai tempat tinggal.

b. Pada saat tinggal sementara mereka akan memperoleh intervensi yang instensif dari pekerja sosial

c. Anak jalanan datang sewaktu-waktu untuk bercakap-cakap, istirahat, bermain, mengikuti kegiatan dan lainlainnya.

d. Rumah Singgah tidak memperkenalkan anak jalanan yang tinggal selamanya, misalkan karena tidak bayar.

e. Anak jalanan yang masih tinggal dengan orang tua saudaranya atau sudah mempunyai tempat tinggal tetap sendirian maupun berkelompok tidak diperkenalkan tinggal menetap di Rumah Singgah, kecuali ada beberapa situasi yang bersifat darurat.

7) Partisipasi

8) Kegiatan yang dilaksanakan di Rumah Singgah didasarkan pada prinsip partisipasi dan kebersamaan. Pekerja sosial dengan anak jalanan memahami masalah, merencanakan, dan merumuskan kegiatan. Dengan cara ini anak dilatih belajar mengatasi masalahnya dan merasa memiliki atau memikirkan kegiatan-kegiatan yang dilaksanakan.

9) Berlajar Bermasyarakat

Anak jalanan seringkali menunjukan sikap dan perilaku yang berbeda dengan norma masyarakat. Rumah Singgah ditempatkan di tengah-tengah masyarakat agar mereka kembali belajar norma dan menunjukan sikap dan perilaku normatif.

Dalam rangka mencapai tujuan serta mendukung fungsi penanganan anak jalanan melalui pendekatan Rumah Singgah didukung dengan program pemberdayaan, dalam hal ini ditempuh berbagai metode agar anak jalanan mengubah keadaan hidupnya seperti menggunakan pelatihan keterampilan, modal untuk kegiatan ekonomi, pendidikan dan juga disamping melayani anak, Rumah Singgah juga melayani orang tua anak, dikarenakan anak jalanan salah satunya muncul oleh kemiskinan dan ketidak harmonisan dalam keluarga.

Dengan melihat uraian diatas maka Rumah Singgah merupakan lembaga pendidikan luar sekolah yang memiliki peranan penting bagi kehidupan anak-anak jalanan, terutama jika dijalankan sesuai dengan fungsinya. Rumah Singgah merupakan upaya agar hak-hak dari anak jalan dapat terpenuh, yang akan mendorong kelancaran proses tumbuh kembang, dengan harapan dapat mengembalikan anak-anak jalanan itu kembali pada kehidupan normal seperti anak-anak lain dan meminimalkan waktu anak dijalan.

\section{Tahapan-tahapan Pemberdayaan Anak Jalanan Melalui Rumah Singgah}

Sesuai dengan jenis kegiatan, pelaksanaan penanganan masalah anak jalanan melalui Rumah Singgah berdasarkan pedoman Penyelenggaraan Pembinaan Anak Jalanan Melalui Rumah Singgah (Depsos, 1999:31-34) pelayanan dan kegiatan Rumah Singgah terbagi ke dalam 6 tahapan. Tahapan-tahapan tersebut mencangkup:

1) Penjangkauan dan pendampingan di jalan, adalah kegiatan kunjungan keluar Rumah Singgah untuk menjangkau anak jalanan sebagai upaya menciptakan kontak pendahuluan dan persahabatan dengan mereka

2) Indentifikasi anak (problem assessment) kegiatan ini merupakan suatu proses untuk menginvestasikan dan mengkaji identitas anak riwayat hidup, masalah, kebutuhan, potensi dan dinamika kehidupan anak jalanan secara cermat dan teliti.

3) Resosialisasi adalah suatu kegiatan merubah sikap dan perilaku anak agar sesuai dengan nilai dan norma sosial.

4) Pemberdayaan untuk anak jalan dimaksudkan sebagai upaya mengangkat anak jalanan dari keterlantaran serta sekaligus mengatasi masalah-masalah yang disandangnya dengan berusaha memenuhi segala keperluan yang dibutuhkan, teruatam yang menyangkut kebutuhan dasar hidupnya.

5) Pemberdayaan untuk orang tua anak jalanan merupakan upaya Rumah Singgah dalam rangka membangun kembali fungsi-fungsi sosial keluarga melalui bimbingan sosial, bimbingan kewirausahaan maupun pendampingan.

6) Terminasi (pengakhiran pelayanan) adalah serangkaian kegiatan yang 
dilakukan pada akhir sebuah proses pemberdayaan anak jalanan. Kegiatan terminasi dilaksanakan dengan maksud agar hasil-hasil yang telah dicapai pada tahap proses pemberdayaan bisa di pertahankan dan secara terus menerus dapat ditumbuh kembangkan.

Dalam tahapan-tahapan kegiatan pelaksanaan pemecahan anak jalanan ini yang berupa pemberdayaan dibutuhkan peran pendamping atau fasilitator yang berasal dari tenaga profesional khususnya peklerja sosial dan penanganan yang serius, agar tahapan-tahapan dalam tiap kegiatan dapat berjalan sesuai dengan tujuan dan efektif, sehingga pelaksanaan pemberdayaan anak jalanan ini dapat berjalan secara berkelanjutan.

\section{Pengalaman Rumah Singgah Anak Jalanan YKAI}

Rumah Singgah Anak Jalanan (RSAJ) merupakan penanganan anak jalanan yang dilakukan oleh Yayasan Kesejahteraan Anak Indonesia (YKAI). Perhatian YKAI terhadap anak jalanan telah dimulai sejak tahun 1989 melalui berbagai kajian penelitian, penerbitan buletin maupun forum ilmiah. RSAJ merupakan lembaga semi institusional (semi panti), bentuknya berbeda dengan sistem panti dan non panti. Program semi institutional bersifat terbuka (open house) selama 24 jam untuk anak jalanan. Anakanak tidak diikat secara formal dan mereka bebas masuk RSAJ kapan pun mereka mau. Meski semi instutional, RSAJ dapat dipandang sebagai centre based, yakni suatu lembaga/panti yang dikelola secara fleksibel menuruti keadaan anak jalanan. RSAJ memang kecil dan hanya bisa menampung sekitar 10 anak, namun pelayanan yang diberikan kepada anak-anak yang tinggal di RSAJ lebih intensif. Di Rumah Singgah ini anak-anak bagai suatu keluarga, karena pekerja sosial yang menangani mereka bertindak sebagai orang tua peganti.

Akan tetrapi, disadari RSAJ mempunyai keterbatasan pekerja sosial dan anak jalanan sendiri masih mempunyai keluarga, maka RSAJ hanya bertindak sebagai jembatan antara anak dan keluarganya atau berupa drop-in centre. Dengan fungsi referal, seperti merujuk kepada keluarga asli, keluarga panti, panti atau bersama teman-temannya. Dengan demikian RSAJ menggunakan pendekatan melalui anak dan keluarga secara sekaligus.

Pencapaian tujuan pelepasan anak dari jalan ternyata bukan pekerjaan mudah, bahkan ada kelompok anak yang tidak bisa dirujuk ke manapun, termasuk juga anakanak jalanan yang memang sudah tidak tinggal dengan orang tuanya serta berkelompok mengontontrak bersama-sama. Proses pelepasan pada kasus ini sangat bervariasi, dari yang bisa dicapai beberapa hari sampai berbulan-bulan.

Dengan pola demikian, RSAJ sendiri dikembangkan dengan tujuan agar:

1) Anak mempunyai cara hidup yang sehat dan normatif

2) Anak mempunyai pengetahuan dan keterampilan

3) Anak dapat menghindarkan diri dari pengaruh negatif jalanan.

Dengan demikian maka selama anak dalam proses pemulangan di RSAJ, anakanak dibekali materi sesuai dengan tujuan di atas, sehingga apabila seorang anak tidak lepas dari jalan, ia akan tetap survive hidup di jalanan.

Kegiatan-kegiatan yang dilakukan untuk mencapai tujuan RSAJ dan sesuai dengan bentuk lembaga, fungsinya, pendekatan yang kemudian di lakukan adalah:

1) Bimbingan sosial

Bimbingan sosial merupakan kegiatan membantu anak untuk mengatasi masalah sehari-hari, baik dalam lingkungan jalanan, pekerjaan, keluarga maupun masalah pribadi. Anak-anakdi tangani secaar satu persatu dengan pendekatan case by case (social case work). Selain itu anak-anak yang mempunyai kesamaan masalah dikelompokan melalui metoda social grup work. Kegiatan ini untuk mengarahkan anak agar mempunyai mekanisme pertahanan diri agar dapat memenuhi kebutuhannya sendiri dan mengatasi ancaman-ancaman di jalanan.

2) Pendidikan jalanan

Banyak anak jalanan yang menghadapi situasi jalanan namun tidak tahu tentang apa yang dihadapinya. Dengan demikian, 
pendidikan jalanan yang diberikan adalah materi pengetahuan yang sesuai dengan situasi dan masalah yang dihadapi anak jalanan. Materi ini berupa pengetahuan umum, kesehatan, sistem sosial, komunikasi dan literacy.

3) Home Visit

Kegiatan ini merupakan penjabaran dari pendekatan keluarga. Home visit dilakukan kepada semua keluarga anak jalanan, utamanya anak jalanan yang sudah kembali ke orang tuanya. Kegiatan ini terbagi empat kegiatan, yakni: 1. Kunjungan keluarga, 2. Mengirim surat, 3. Datang ke RSAJ dan 4. Meneriman surat. Dalam setiap kunjungan dilakukan bimbingan pengasuhan anak kepada orang tua dan mengidentifikasi anak yang sudah pulang. Dalam perkermbangannya, kepada orang tua anak diberikan pula pinjaman uang. Pinjaman ini digunakan untuk masalah sehari-hari atau income generating.

Dari uraian diatas terlihat bahwa RSAJ bertumpu pada pengasuhan anak dan kelurganya, selain itu RSAJ juga mengarahkan anak binaan dan keluarganya agar dapat mandiri, berusaha bisa mengatasi masalah secara benar dan pemenuhan hidup sehari-hari.

Untuk mencapai tujuannya, beberapa hambatan sering kali terjadi. hambatan tersebut antara lain:

1) Keterbatasan pekerja sosial yang hanya dua orang, tidak maksimal melaksanakan kegiatan.

2) Anak binaan yang menyebar di luar Jakarta sehingga sulit memonitor

3) Beberapa anak sangat mobile: sehingga tidak mudah untuk dilayani. Tata Sudrajat (1996:159-164).

\section{Kesimpulan dan Saran}

\section{Kesimpulan}

Anak jalanan merupakan kelompok anak marjinal juga menyebutkan Marjinal, rentan, dan eksploitasi yang sebagian besar waktunya dipergunakan untuk mencari nafkah atau berkeliaran di jalan atau tempattempat umum lainnya. Akan tetapi, keberadaan anak jalanan secara umum dibagi kedalam tiga kelompok kategori yaitu Children of the street, children on the street dan children at high risk. Dapat diketahui terjadinya anak jalanan bukan hanya disebabkan dari faktor ekonomi saja, namun faktor keluarga dan lingkungan juga cukup berpengaruh terhadap munculnya anak jalanan. Dengan demikian berbagai faktor akan mempengaruhi keberadaan anak jalanan.

Departemen Sosial RI bekerja sama dengan UNDP (United Nation United Programe) dalam proyek INS/94/007 pembuatan Rumah Singgah (Departemen Sosial,1997:31). Dalam pendekatan ini penanganannya tidak dilakukan sendirisendiri. Namun, dilakukan secara terpadu dari tiga pendekatan yang pernah ada. Sehingga dalam pendekatan Rumah Singgah tercangkup pula pendekatan street based yaitu dengan melakukan penjangkauan dan pendampingan. Pendekatan centre based dimana Rumah Singgah merupakan tempat persinggahan bagi anak, selain itu Rumah Singgah juga melakukan kerja sama dengan pihak lain sebagai rujukan dalam melaksanakan kegiatan centre based ini. Sedangkan pendekatan community based rumah singgah melakukan kerja sama atau menggali sumber yang ada di dalam masyarakat sehingga penanganan anak jalana dapat sinkron dengan kehidupan dan kebutuhan di masyarakat.

Selain itu Rumah Singgah juga melakukan kegiatan berupa bimbingan dan pemberdayaan. Bimbingan dilakukan baik terhadap anak jalanan maupun terhadap orang tua anak jalanan. Bimbingan dilakukan baik dibutuhkan maupun tidak dibutuhkan oleh anak jalan dan orang tua anak jalan. Bimbingan ini dilaksanakan dengan cara mendatangi anak jalanan atau orang tua anak jalanan.

Sedangkan program pemberdayaan dalam pelayanan dan kegiatan Rumah Singgah terbagi ke dalam 6 tahapan. Tahapan-tahapan tersebut mencangkup: Penjangkauan, Identifikasi anak, resosialisasi, pemberdayaan anak, pemberdayaan orang tua dan terminasi. Program pemberdayaan di tujukan untuk meningkatkan kemampuan anak jalanan dan orang tua anak jalan sehingga mempunyai pengetahuan yang 
meningkat, dapat mandiri sehingga anak jalan tidak beraktivitas lagi dijalan.

Pemberdayaan bagi orang tua dimaksudkan agar orang tua dapat meningkatkan kemampuannya dalam mencukup kebutuhan keluarganya. Dengan demikian anak terhindar untuk beraktivitas dijalan. Selain itu orang tua atau keluarganya dapat memenuhi kebutuhan dasar anggota keluarganya.

Salah satu Rumah Singgah Anak Jalanan (RSAJ) yang telah ada sejak tahun 1989 adalah Yayasan Kesejahteraan Anak Indonesia (YKAI). RSAJ sendiri dikembangkan dengan tujuan agar: Anak mempunyai cara hidup yang sehat dan normatif, Anak mempunyai pengetahuan dan keterampilan, Anak dapat menghindarkan diri dari pengaruh negatif jalanan. Kegiatan-kegiatan yang dilakukan untuk mencapai tujuan RSAJ dan sesuai dengan bentuk lembaga, fungsinya, pendekatan yang kemudian di lakukan: bimbingan sosial, pendidikan jasmani dan home visit.

Dari uraian diatas terlihat bahwa RSAJ bertumpu pada pengasuhan anak dan kelurganya, selain itu RSAJ juga mengarahkan anak binaan dan keluarganya agar dapat mandiri, berusaha bisa mengatasi masalah secara benar dan pemenuhan hidup sehari-hari.

Akan tetapi, dalam pencapaiannya RSAJ ada beberapa hambatan yaitu: Keterbatasan tenaga ahli seperti pekerja sosial, Anak binaan yang menyebar di luar jangkauan dan Beberapa anak jalanan yang memiliki mobilitas yang tinggi sehingga sulit untuk diberikan pelayanan.

\section{Saran}

Optimalisasi pelaksanaan dengan
menerapkan metode community base, dimana penanganan anak jalan dilakukan bersama-sama dengan warga masyarakat setempat dan pemerintah daerah khususnya kota setempat mengadakan penanganan anak jalanan ke dalam rencana pembangunan di wilayahnya masing-masing dan Lembaga Swadaya Masyarakat bertindak sebagai pengawal dalam pelaksanaan pemberdayaan tersebut.

Meningkatkan jumlah pekerja profesional khususnya pekerja sosial yang merupakan profesi yang sangat memahami persoalan dan permasalahan sosial anak jalanan di Rumah Singgah dan Lembaga Swadaya Masyarakat.

Satu hal hal yang penting: program apapun yang akan dilakukan da pendekatan apa yang dipilih, modal awal yang dibutuhkan untuk menangani permasalahan anak jalanan adalah sikap empati dan komitmen yang benar-benar tulus dari kita semua. Tanpa dilandasi dan dipandu oleh kedua hal ini, maka jangan heran jika nasib anak-anak jalanan tidak akan pernah selesai sampai ke akarnya.

\section{Daftar Pustaka}

Armai Arief. 2002. Rumah Singgah Sebagai Tempat Alternative Pemberdayaan Anak Jalanan. Dalam Jurnal Fajar. Jakarta: LPM UIN.

Astutianny April, Maria. 2001. Pemberdayaan Anak Jalanan Di DKI Jakarta: Studi Kasus di Rumah Singgah Setia Kawan II Jakarta. Tesis. Jakarta: Universitas Indonesia.

Amal, Bakhrul Khair. 2003. Pemberdayaan Anak Jalanan Melalui Rumah Singgah: Studi Kebijakan Penanganan Anak Jalanan di Indonesia. Tesis. Depeok: Universitas Indonesia

Departemen Sosial RI. 1999. Pedoman Penyelenggaraan Pembinaan Anak Jalanan Melalui Rumah Singgah. Jakarta: Departemen Sosial RI.

Dubois, Brenda. Milley, Karla Kongsrud. 1992. Social Work An Empowering Profession. Boston: Allyn and Bacon.

Hurlock, B. Elizabeth. 1980. Psikologi Perkembangan. Jakarta: Erlanga.

Ife, Jim. 1995. Community Development: Creating Community Alternative Vision, Analysis and Practic. Australiang: Longman.

Isbandi Rukminto, Adi. 2001. Pemberdayaan Pengembangan Masyarakat dan Intervensi Komunitas (Pengantar Pada Pemikiran dan Pendekatan Praktis). Jakarta: Lembaga Penerbit Fakultas Ekonomi Universitas Indonesia.

Isbandi, Rukminto, Adi. 2008. Intervensi Komunitas dan Pengembangan Masyarakat: Sebagai Upaya Pemberdayaan Masyarakat. Depok: PT RajaGrafindo Persada 
Lusk, Mark. W. 1984. Street Children Program in Latin America. Journal of Sociology \& Social Welfare

Moleong, Lexy J. 2004. Metodologi penelitian Kualitatif. Bandung: PT. Rosdakarya.

Midgley, James. 1995. Social Development: The Development Perspective in Social Welfare. London: Sage Publication Inc.

Mulandar, Surya. 1996. Dehumanisasi Anak Marjinal: Berbagai Pengalaman Pemberdayaan. Bandung:Akatiga

Sudrajat, A. 1989. Profil Anak Jalanan di DKI Jakarta. Jakarta: Badan Penelitian dan Pengembangan Sosial. Departemen Sosial RI.

Suyanto, Bagong. 2010. Masalah Sosial Anak. Jakarta:Kencana Prenada Media Group

Sanusi, Makmur. (1995) Beberapa Temuan Lapangan Survey Anak Jalanan dan Rencana Penangannya di Jakarta dan Surabaya. Jakarta. Departemen Sosial, UNDP.

Web:

http://cumadiindonesia.com/makinmaraknya-anak-jalanan-siapa-yang bertanggung-jawab/ di unduh pada tanggal 27 Maret 2015 pukul 17.28 